\title{
MISKONSEPSI PENDIDIKAN GRATIS
}

\author{
Oleh: Hardianto Rahman 1
}

$* * *$

\begin{abstract}
Abstrak
Penelitian ini bertujuan untuk yaitu untuk mengungkapkan miskonsepsi tentang pendidikan gratis. Metode yang digunakan dalam penelitian ini diantaranya yaitu: metode kritis, , metode dialektis dan metode skolastik. Penelitian ini termasuk dalam penelitian kepustakaan. Penulis berusaha mencari data-data, teori-teori yang berkaitan dengan persoalan yang diangkat dalam berbagai literature atau referensi yang ditemukan penulis kemudian dibandingkan dengan menggunakan metode tersebut di atas.

Kesimpulan dari penelitian ini ialah "Program Pendidikan Gratis" di daerah sebaiknya dihilangkan dan tidak lagi dipergunakan sebagai nomenklatur oleh jajaran pemerintahan mana pun. Dengan menhilangkan pendidikan gratis, maka pemerintahan pada berbagai tingkatan mana pun tak mungkin lagi leluasa mempolitisasi pendidikan hanya untuk kepentingan super pragmatis kekuasaan
\end{abstract}

Kata Kunci: Paradigma, Metodologi, dan Praktik Kependidikan

\section{PENDAHULUAN}

\section{A. Latar Belakang}

$\mathrm{K}$ eluhan terhadap biaya pendidikan mahal terdengar di mana-mana. Ini adalah ironi di tengah gencarnya propaganda politik tentang pendidikan gratis. Namun, kontradiksi ini mestinya dengan mudah bisa dimaklumi mengingat pendidikan adalah dunia profesional yang jelas-jelas membutuhkan dana untuk menuju kualitas. Di lain pihak, politisi mengumbar slogan pendidikan gratis semata untuk pencitraan dan diingkari setelah menjabat.

Impian masyarakat akan datangnya pendidikan gratis yang telah ditunggutunggu dari sejak zaman kemerdekaan Republik Indonesia telah muncul dengan seiring datangnya fenomena pendidikan gratis untuk Sekolah Dasar dan Sekolah Lanjutan Tingkat Pertama. Fenomena pendidikan gratis ini memang sangat ditunggu-tunggu, pasalnya Pemerintah mengeluarkan dana BOS (Biaya Operasional Sekolah) untuk menutupi harga-harga buku yang kian hari kian

1 Dosen Tetap pada STAI Muhammadiyah Sinjai 


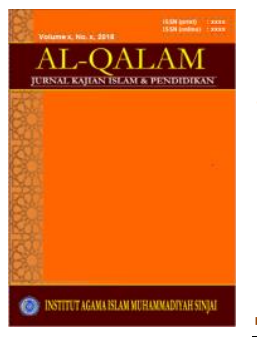

AL-QALAM

Jurnal Kajian Islam \& Pendidikan

Volume 06 No 012014

ISSN (print) : 1858-4152

ISSN (online) : -

Homepage : http://journal.iaimsinjai.ac.id/index.php/al-qalam

melambung, sumbangan ini itu, gaji guru yang tidak cukup dan biaya-biaya lainnya.

Namun, apa pun faktanya, yang jelas dunia pendidikan di negeri ini sangat mahal. Di tengah banyaknya gelontoran subsidi oleh pemerinmtah, baik dalam bentuk bantuan operasional sekolah (BOS) dan dana pendamping lainnya, banyak sekolah tetap leluasa melakukan praktik pungutan.

Dilihat dari perkembanganya, fenomena ini tidak lepas dari pro dan kontra. Bagi yang pro dengan program-program itu mengatakan bahwa itu adalah upaya pemerintah untuk meningkatkan mutu pendidikan dan penurunan angka anak putus sekolah, pendidikan gratis bagi orang tua bisa mengurangi beban pikirannya untuk masalah biaya pendidikan dan tidak ada lagi anak-anak yang tidak boleh ikut ujian hanya karena belum bayar iuran sekolah. Sedangkan yang kontra berkata pemerintah bagaikan pahlawan kesiangan, Hal ini dikarenakan telah ada yang lebih dulu melakukan hal tersebut, yaitu LSM-LSM yang concern pada bidang pendidikan dan penanganan masyarakat tak mampu. Adanya kurang rasa harus sekolah, kesadaran akan pendidikan sangat kurang, anak lebih mementingkan pekerjaan dari pada harus sekolah yang tidak mengeluarkan apaapa.

Sehubungan dengan pendidikan tentunya sangat berkaitan dengan mutu pendidikan. Sekolah menjadi bermutu karena ditopang oleh peserta didik yang punya semangat belajar. Mereka mau belajar kalau ada tantangan, salah satunya tantangan biaya. Generasi muda dipupuk untuk tidak mempunyai mental serba gratisan. Sebaiknya mental gratisan dikikis habis. Kerja keras, rendah hati, toleran, mampu beradaptasi, dan takwa, itulah yang harus ditumbuhkan agar generasi muda ini mampu bersaing di dunia internasional, mampu ambil bagian dalam percaturan dunia, bukan hanya menjadi bangsa pengagum, bangsa yang rakus mengonsumsi produk. Paling susah adalah pemerintah menciptakan kondisi agar setiap orangtua mendapat penghasilan yang cukup sehingga mampu membiayai pendidikan anak-anaknya.

Tidak hanya murid saja melainkan guru yang terkena imbas dari pendidikan gratis ini. Kebanyakan dari guru sekolah gratisan mengalami keterbatasan mengembangkan diri dan akhirnya akan kesulitan memotivasi peserta didik sebab harus berpikir soal "bertahan hidup". Lebih celaka lagi jika guru berpikiran : pelayanan pada peserta didik sebesar honor saja. Jika demikian situasinya, maka "jauh panggang dari api" untuk menaikkan mutu pendidikan. Sekolah, terutama sekolah swasta kecil, akan kesulitan menutup biaya operasional sekolah, apalagi menyejahterakan gurunya. Pembiayaan seperti listrik, air, perawatan gedung, komputer, alat tulis kantor, transpor, uang makan, dan biaya lain harus dibayar. Mencari donor pun semakin sulit. Sekolah masih bertahan hanya berlandaskan semangat pengabdian pengelolanya. Tanpa iuran dari peserta didik, bagaimana akan menutup pembiayaan itu. 


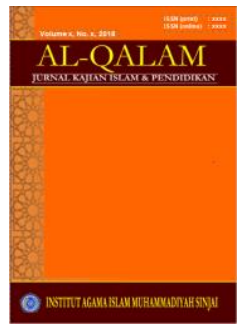

\section{B. Rumusan Masalah}

Adapun rumusan masalah dalam tilisan akan di fokuskan pada miskonsepsi tentang pendidikan gratis.

\section{Tujuan dan Kegunaan Pembahasan}

Berangkat dari formulasi rumusan masalah di atas, maka hal mendasar yang menjadi tujuan dari pembahasan tulisan ini, yaitu untuk mengungkapkan miskonsepsi tentang pendidikan gratis.

\section{Metode Pembahasan}

Louis O. Kattsoff menggambarkan metode pemikiran filsafat ke dalam beberapa langkah. Pertama, mengumpulkan pengetahuan manusia sebanyak mungkin, lalu dikritik dan dinilai untuk menemukan hakikatnya dalam suatu sistem. Kedua, melakukan analisis secara hati-hati alasan yang dipergunakan mengenai suatu masalah. Ketiga, dengan jalan meragukan, mengajukan pertanyaan, serta menghubungkan, kemudian mencari jawaban yang lebih baik dari berbagai jawaban yang telah tersedia.

Selanjutnya setelah langkah ketiga di atas adalah mencari alasan, keruntutan dan memahami pengetahuan itu. Langkah kelima adalah menyusun bagan koheren, runtut dan rasional, sebagai suatu bagan yang secara logis berhubungan satu dengan yang lain. Dan langkah ketujuh ialah menyusun bagan konseptual tentang dunia yang dihadapi manusia secra komprehensif.2

Metode-metode yang paling dekat digunakan secara praktis dalam kepentingan tulisan ini, dapat ditampilkan antara lain: (1) metode kritis, yaitu bersifat analisa istilah dan pendapat, merupakan hermeneutika yang menjelaskan keyakinan dan memperihatkan pertentangan; (2) metode dialektis, yaitu dengan jalan mengikuti dinamika pikiran atau alam sendiri menurut trisde tesis, antithesis, dan sintesis, dicapai hakikat kenyataan; (3) metode skolastik, yaitu bersifat sintetik-deduktif. Dengan bertitik tolak dari defenisi-defenisi atau prinsip-prinsip yang jelas, dengan sendirinya ditarik kesimpulan-kesimpulan.

\section{PEMBAHASAN Analisis Konseptual}

Fenomena yang telah di bahas dalam pendahuluan tersebut di atas tidak terlepas dari penentu kebijakan yang mencetuskan kebijakan-kebijakannya dalam

2 Abdul Munir Mulkan, Paradigma Intelektual Muslim: Pengantar Filsafat Pendidikan dan Dakwah. Sipress, Yogyakarta, 1993. hal. 39. 
pendidikan. Tulisan ini akan menfokuskan pada tinjauan pendidikan gratis dalam persfektif politik pendidikan. Apakah pendidikan gratis itu adalah kebijakan politik atau hanya sekedar politisasi pendidikan?

Berbicara mengenai kebijakan pendidikan tidak dapat dilepaskan dengan keadaan politik. Keterkaitan pendidikan dan politik yang ada pada suatu negara hampir sulit untuk dipisahkan, karena pendidikan mempunyai peran yang besar terhadap negara melalui lembaga pendidikan untuk mendidik warga negara agar dapat berguna dan berhasil bagi negara tersebut. 3

Realita pendidikan di Indonesia dapat dikatakan berjalan tertatih-tatih (tadak sesuai dengan harapan) sejak awal kemerdekaan, mulai dari orde lama (1945-1965), pada masa orde baru (1965-1998) dan pada masa orde reformasi (1998-2003) pendidikan nasional belum memberi hasil yang optimal. Kegagalankegagalan pendidikan di Indonesia pada dasarnya berakar pada persoalan ketiadaan kerangka pembangunan pendidikan nasional jangka panjang yang aspiratif, demokratis dan partisipatif serta tidak adanya konsistensi dan kesinambungan dalam melaksanakan rencana yang sudah ada yang tidak tergantung dengan masa jabatan menteri.

Hal ini dapat dilihat adanya pergantian pemerintah sebanyak 5 kali. Dengan adanya kebiasaan pergantian pemerintahan, maka berganti pula kabinet yang menduduki jabatan pemerintahan dan secara otomatis kabinet tersebut juga memunculkan kebijakan- kebijakan yang baru pula termasuk kebijakan pendidikan pada bidang kurikulum. Sebagai contoh sebelum Indonesia merdeka setidaknya telah terjadi dua kali perubahan kurikulum, yang pertama ketika di jajah belanda kurikulum disesuaikan dengan kepentingan politiknya. Kedua ketika dijajah Jepang kurikulum disesuaikan dengan kepentingan politiknya yang bersemangatkan kemiliteran dan kebangunan Asia Timur Raya. Kemudian setelah Indonesia merdeka pra orde baru terjadi pula dua kali perubahan kurikulum, yang pertama dilakukan dengan dikeluarkannya rencana pelajaran tahun 1947 yang menggantikan seluruh sistem pendidikan kolonial, kemudian pada tahun 1952 kurikulum ini mengalami penyempurnaan dan diberinanama rencana Pelajaran terurai 1952. Perubahan kedua terjadi dengan dikeluarkannya rencana pendidikan tahun 1964, perubahan tersebut terjadi karena merasa perlunya peningkatan dan pengejaran segala ketertinggalan dalam ilmu pengetahuan khususnya ilmu-ilmu alam dan matematika.

Saat orde baru terlahirpun kurikulum mengalami beberapa kali perubahan. Perubahan pertama terjadi dengan dikeluarkannya kurikulum 1968 yang didasari oleh adanya tuntutan untuk mengadakan perubahan secara radikal pemerintahan orde lama dalam segala aspek kehidupan termasuk pendidikan. Perubahan kedua terjadi dengan diterbitkannya kurikulum tahun 1975 (disempurnakan dengan kurikulum 1976 dan 1977). Perubahan ketiga terjadi dengan diberlakukannya

3 Tabrani \& Samsul Arifin, Islam Pluralitas Budaya dan Politik, (Yogyakarta: SI Press, 1994), h. 123 
kurikulum tahun 1984. Dan Perubahan keempat terjadi Ketika di negara kita diberlakukan Undang-undang Sistem pendidikan Nasional (UUSPN) pada tahun 1989 beserta seperangkat peraturan pemerintah yang mengatur lebih lanjut pelaksanaan UUSPN tersebut, menyebabkan perlunya pembuatan atau penyusunan kurikulum yang sesuai dengan rumusan pasal-pasal yang tercantum dalam UUSPN dan peraturan pemerintahnya. Maka pada Tahun 1994 di negara kita diberlakukan kurikulum baru sesuai dengan keputusan menteri Pendidikan dan Kebudayaan Nomor 060/U/1993 tanggal 25 Februari 1993.

Perubahan dan perbaikan kurikulum itu wajar terjadi dan memang harus terjadi, karena kurikulum yang disajikan harus senantiasa sesuai dengan segala perubahan dan perkembangan yang terjadi. Hal ini sebagaimana dikemukakan oleh Subandijah, Apabila kurikulum itu dipandang sebagai alat untuk mencapai tujuan pendidikan, maka kurikulum dalam kedudukannya harus memiliki sifat anticipatori, bukan hanya sebagai reportorial. Hal ini berarti bahwa kurikulum harus dapat meramalkan kejadian di masa yang akan datang, tidak hanya melaporkan keberhasilan peserta didik.4 Hal senada juga diungkapkan oleh Syafaruddin, bahwa perubahan merupakan suatu keniscayaan.5

Namun dengan adanya perubahan tentu harus melalui perumusan tentang kebijakan pendidikan, Sebelum diimplementasikan hasil kebijakan yang telah dirumuskan, maka hendaknya dikomunikasikan secara terus menerus kepada khalayak. Suatu kebijakan pendidikan seperti pendidikan gratis tentunya harus dibahas bersama dengan yang concern di bidang pendidikan tentunya. Supaya khalayak memahaminya lebih dalam, sebab tidak diterimanya suatu kebijakan tersebut, bisa jadi bukan karena kebijakan yang dirumuskan tersebut kurang asfiratif, melainkan karena belum dipahami secara mendalam oleh khalayak.6 Ketika komunikasi minim dilakukan maka akan menyebabkan kurang saling memahami dan tidak ada kemesraan yang akhirnya timbul saling mencurigai satu sama lain yang kemudian terjadi demo dan bentrok.

Dalam realita, di dunia ini tak ada negara yang tak turut campur atas pendidikan warga negaranya, maka di dunia pendidikan juga ada potensi-potensi konfliknya, terutama yang berkaitan dengan upaya menjembatani antara kepentingan masyarakat dan pemerintah. Karena masyarakat bertekat mewariskan kepentingan-kepentingannya sendiri kepada generasinya, sementara pemerintah

4 Subandijah, Pengembangan dan Inovasi Kurikulum, (Jakarta :Raja Gravindo Persada, 1993), h. 3

5 Syafaruddin, Evektivitas Kebijakan Pendidikan: konsep, strategi, dan aplikasi kebijakan menuju organisasi sekolah efektif, (Jakarta: Rineka Cipta, 2008), h. 15

6 Ali Imron, Kebijaksanaan Pendidikan Indonesia, (Jakarta: Bumi Aksara, 2008), h. 57 
juga berkepentingan dengan mendidik warga negara yang baik menurut paham pemerintah, maka tak mustahil antara mesyarakat dan pemerintah berlawanan. Tawar-menawar antara banyaknya kepentingan lembaga- lembaga, masyarakat, politik yang mesti dimasukkan ke dalam kurikulum adalah salah satu wujud dari sekian banyak terjadinya konflik kepentingan antara keduanya.

Carut marutnya pendidikan kita tidak terlepas dari campur tangan pemerintah sebagai pemangku kebijakan. Politik pendidikan nasional sejatinya memberi andil, untuk tidak dikatakan menjadi penyebab utama, karena apa yang terjadi di lapangan adalah manifestasi dari regulasi yang ada. Setiap undangundang sistem pendidikan nasional pastilah tidak steril dari berbagai kepentingan, utamanya kepentingan pragmatis dan kepentingan ideologis. Kepentingan pragmatis dapat berupa upaya mempertahankan kekuasaan atau mengeruk materi, sedangkan kepentingan ideologis berkaitan dengan upaya menggiring masyarakat pada ideologi atau paham tertentu yang dikehendaki penguasa.

Hidup adalah masalah, begitulah persepsi kebanyakan orang, masalah terbagi dua bagian pertama masalah pribadi yaitu masalah yang hanya dialami oleh satu orang dan orang tersebut mampu menyelesaikan masalah yang muncul dan masalah kelompok, kedua golongan atau masalah publik yaitu suatu masalah yang menyerap perhatian khalayak ramai yang mempunyai tujuan yang sama hingga pada pelaksanaanya. Maka masalah pendidikan yang merupakan bagian dari masalah publik, ini dapat dikatakan masalah prosuderal dengan regulasi, yang dapat menyedot perhatian publik. Dengan otomatis politik bermain di dalamnya, namun tidak semua masalah yang muncul menjadi masalah namun pada sekelompok golongan atau seseorang menjadi sebuah keuntungan terhadap masalah yang muncul.

Pendidikan dan politik adalah dua elemen penting dalam sistem sosial politik di setiap negara, baik negara maju maupun negara berkembang. Keduanya sering dilihat sebagai bagian-bagian yang terpisah yang satu sama lain tidak memiliki hubungan apa-apa. Padahal keduanya bahu membahu dalam proses pembentukan karakteristik masyarakat di suatu negara.7 Kata politik didalam kamus bahasa Indonesia adalah pengetahuan tentang ketatanegaraan atau kenegaraan seperti tatacara pemerintah, dapat pula diartikan segala urusan tindakan, kebijakan, siasat, dan sebagainya mengenai pemerintah suatu negara atau negara lain.

Politik pendidikan adalah suatu pendekatan atau metode yang didasarkan kepada kebudayaan nasional untuk mempengaruhi pihak-pihak yang memiliki kekuasaan atau wewenang untuk mencapai tujuan pendidikan nasional. Politik pendidikan yang menjadi panduan dalam perjalanan pendidikan nasional, dengan adanya politik pendidikan maka akan terbentuk konsep yang tepat, kuat,dan kokoh. Yang nantinya diharapkan pendidikan mampu melahirkan sumber daya

7 M. Sirozi, Politik pendidikan. (Jakarta : PT Raja Grafindo, 2005), h. 1 


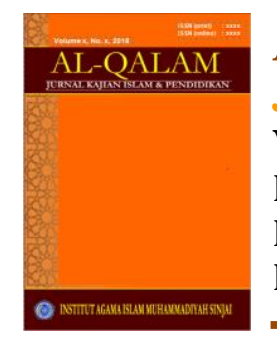

AL-QALAM

Jurmal Kajian Islam \& Pendidikan

Volume 06 No 012014

ISSN (print) : 1858-4152

ISSN (online) : -

Homepage : http://journal.iaimsinjai.ac.id/index.php/al-qalam

manusia yang memiliki kecerdasan baik secara intelektual, emosional, maupun sosial.

Selama ini pendidikan, jarang digunakan sebagai instrumen politik dalam menentukan arah dan bentuk masa depan. Pendidikan lebih banyak menjadi korban politik dan bukan katalis politik dalam mewujudkan visi dan misi pembangunan. Implikasi nyata dari kesadaran ini, yaitu perlunya pemberdayaan pendidikan sebagai bagian penting dari proses politik di Indonesia, khususnya politik karakter bangsa bagi pembangunan negara yang absolut. Pendidikan adalah instrumen penting dalam membangun karakter bangsa dan pembangkitan kesadaran atau nasionalisme bangsa. Sayangnya, kita belum mampu merumuskan dan atau menggunakan pendidikan sebagai katalis pembangunan, atau pendidikan sebagai instrumen politik kebangsaan. 8 Politik pendidikan adalah sektor penting bagi masa depan Indonesia. Sebab, dengan politik pendidikan ini, Indonesia bisa menentukan potret hari esok dari saat ini.

Setiap kesuksesan suatu negara dilandasi oleh pendidikan yang kokoh. Kesuksesan dalam politik, ekonomi, sosial, budaya, maupun agama dilandasi oleh suksesnya pendidikan. Pendidikan merupakan soft power, kekuatan sejati yang tidak kasat mata, tetapi semua orang memerlukan dan merasakan kekuatannya. Pendidikan memberikan pengaruh politis yang amat besar dalam kehidupan manusia. Manusia yang terdidik dengan baik dan sehat ia akan mampu mengkreasi diri untuk mengubah pendidikan menjadi media berpolitik yang sehat dan sekaligus mampu mendidik politik lewat pendidikan. Pendidikan politik dan politik pendidikan bisa berintegrasi, interkoneksi, tetapi juga bisa bermusuhan.

Tokoh liberalisme pendidikan asal Amerika Latin Paulo Freire menegaskan bahwa bagaimanapun kebijakan politik sangat menentukan arah pembinaan dan pembangunan pendidikan. Freire memandang politik pendidikan memiliki nilai penting untuk menentukan kinerja pendidikan suatu negara. Bangsa yang politik pendidikannya buruk, maka kinerja pendidikannyapun pasti buruk. Sebaliknya, negara yang politik pendidikannya bagus, kinerja pendidikannya pun juga akan bagus.

Hubungan timbal balik antara politik dan pendidikan dapat melalui tiga aspek, yakni: pembentukan sikap kelompok (Group Attitudes), masalah pengangguran (unemployment), serta peranan politik kaum cendekia (the political role of the intelegensia). Hubungan antara politik dan pendidikan terwujud ke dalam berbagai bentuk yang berbeda-beda, sesuai dengan karakteristik seting sosial politik dimana hubungan itu terjadi. Negara-negara berkembang, pendidikan formal memiliki peran yang penting dan nyata dalam mencapai

8 Cecep Darmawan. Politik Pendidikan Indonesia. Harian Pikiran Rakyat, Senin 4 Mei 2009. 


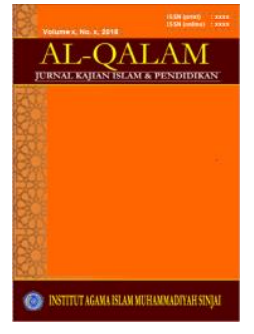

AL-QALAM

Jurnal Kajian Islam \& Pendidikan

Volume 06 No 012014

ISSN (print) : 1858-4152

ISSN (online) : -

Homepage : http://journal.iaimsinjai.ac.id/index.php/al-qalam

perubahan politik dan dalam proses regenerasi pemimpin elite politik baru. Proses dan lembaga-lembaga pendidikan memiliki aspek dan wajah politik yang banyak, serta memiliki beberapa fungsi penting yang berdampak pada sistem politik, stabilitas, dan praktik sehari-harinya. Pendidikan merupakan wilayah tanggung jawab pemerintah yang besar. Pendidikan publik bersifat politis karena dikontrol oleh pemerintah dan memengaruhi kredibilitas pemerintah.9

Political science adalah ilmu social yang berkenaan dengan deskripsi kekuasaan dan analisis politik. Khususnya institusi pemerintahan yang memproses dan membuat penggunaan fakta dan metode dari ilmu social. Politik kekuasaan secara sederhana ialah menentukan siapa memperoleh apa, dimana, dan kapan. Politik sebagai jenis khusus usaha seseorang dalam memperjuangkan kekuasaan politik. Dalam teori system social, politik dan pendidikan berada dalam satu system yang saling berhubungan dekat. Apalagi dari kiprahnya, para pendidik selalu memelihara politik karena proses pendidikan yang memberikan sumber nilai dan memberikan kontribusi terhadap politik. Pendidikan memberikan kontrisbusi yang sangat siknifikan terhadap politik teruama stabiliasi dan transformasi system politik.

\section{KESIMPULAN}

Dari konseptualisasi teori-teori di atas maka langkah-langkah yang mesti dilakukan dalam menanggapi fenomena pendidikan gratis adalah dengan Bercermin dari stakeholder yang sukses dalam memutuskan kebijakan pendidikan dilakukan oleh Bill Clinton, ketika menjabat Gubernur Arkansas dan dilanjutkannya saat menjabat presiden Amerika Serikat, yakni selalu melibatkan 3 (tiga) aktor utama dalam proses sebuah kebijakan pendidikan secara sinergis, mereka adalah unsur; (1) pemerintah, (2) para guru, dan (3) pakar pendidikan yang dipandang beliau lebih memahami kotak hitam (black box) persoalan pendidikan, bukan birokrat bermental proyek.10 Disini jelas terlihat bahwa pengambilan keputusan kebijakan di Amerika sangat sinergi karena aktor yang berberan ialah orang-orang yang berkompetensi di bidang pendidikan sehingga para aktor mengetahui apa yang diharapkan oleh pasar pendidikan dan percepatan global. Berbda halnya dengan negara Indonesia aktor yang di tetapkan oleh pemerintah ialah orang-orang yang mempunyai power didalam kalangan elit politik tanpa melibatkan ahli pendidikan jikapun ada keputusan dominan pada elit politik.

9 M. Sirozi, lot.cit

10 Aswandi, Proses sebuah kebijakan, http://www.facebook.com/topic.php, Senin, 20 Juli 2009 , download tanggal 8 Januari 2011. 


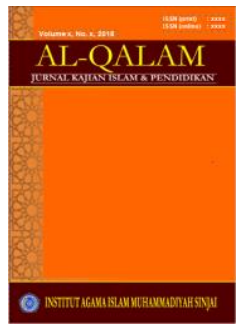

AL-QALAM

Jurnal Kajian Islam \& Pendidikan

Volume 06 No 012014

ISSN (print) : 1858-4152

ISSN (online) : -

Homepage : http://journal.iaimsinjai.ac.id/index.php/al-qalam

Dalam merumuskan kebijakan pendidikan, para pembuat kebijakan hendaknya memperhatikan beberapa karakteristik khusus. Adapun karakteristik yang dimaksud adalah :

1. Memiliki tujuan pendidikan, Kebijakan pendidikan harus memiliki tujuan, namun lebih khusus, bahwa ia harus memiliki tujuan pendidikan yang jelas dan terarah untuk memberikan kontribusi pada pendidikan.

2. Memenuhi aspek legal-formal, Kebijakan pendidikan tentunya akan diberlakukan, maka perlu adanya pemenuhan atas pra-syarat yang harus dipenuhi agar kebijakan pendidikan itu diakui dan secara sah berlaku untuk sebuah wilayah. Maka, kebijakan pendidikan harus memenuhi syarat konstitusional sesuai dengan hirarki konstitusi yang berlaku di sebuah wilayah hingga ia dapat dinyatakan sah dan resmi berlaku di wilayah tersebut. Sehingga, dapat dimunculkan suatu kebijakan pendidikan yang legitimat.

3. Memiliki konsep operasional, Kebijakan pendidikan sebagai sebuah panduan yang bersifat umum, tentunya harus mempunyai manfaat operasional agar dapat diimplementasikan dan ini adalah sebuah keharusan untuk memperjelas pencapaian tujuan pendidikan yang ingin dicapai. Apalagi kebutuhan akan kebijakan pendidikan adalah fungsi pendukung pengambilan keputusan.

4. Dibuat oleh yang berwenang, Kebijakan pendidikan itu harus dibuat oleh para ahli di bidangnya yang memiliki kewenangan untuk itu, sehingga tak sampai menimbulkan kerusakan pada pendidikan dan lingkungan di luar pendidikan. Para administrator pendidikan, pengelola lembaga pendidikan dan para politisi yang berkaitan langsung dengan pendidikan adalah unsur minimal pembuat kebijakan pendidikan.

5. Dapat dievaluasi, Kebijakan pendidikan itu pun tentunya tak luput dari keadaan yang sesungguhnya untuk ditindaklanjuti. Jika baik, maka dipertahankan atau dikembangkan, sedangkan jika mengandung kesalahan, maka harus bisa diperbaiki. Sehingga, kebijakan pendidikan memiliki karakter dapat memungkinkan adanya evaluasi terhadapnya secara mudah dan efektif.

6. Memiliki sistematika, Kebijakan pendidikan tentunya merupakan sebuah sistem jua, oleh karenanya harus memiliki sistematika yang jelas menyangkut seluruh aspek yang ingin diatur olehnya. Sistematika itu pun dituntut memiliki efektifitas, efisiensi dan sustainabilitas yang tinggi agar kebijakan pendidikan itu tidak bersifat pragmatis, diskriminatif dan rapuh strukturnya akibat serangkaian faktor yang hilang atau saling berbenturan satu sama lainnya. Hal ini harus diperhatikan dengan cermat agar pemberlakuannya kelak tidak menimbulkan kecacatan hukum secara internal. Kemudian kebijakan pendidikan harus bersepadu dengan 
kebijakan lainnya; kebijakan politik; kebijakan moneter; bahkan kebijakan pendidikan di atasnya atau disamping dan dibawahnya.

"Program Pendidikan Gratis" di daerah sebaiknya dihilangkan dan tidak lagi dipergunakan sebagai nomenklatur oleh jajaran pemerintahan mana pun. Dengan menhilangkan pendidikan gratis, maka pemerintahan pada berbagai tingkatan mana pun tak mungkin lagi leluasa mempolitisasi pendidikan hanya untuk kepentingan super pragmatis kekuasaan.

\section{DAFTAR PUSTAKA}

Ali Imron, Kebijaksanaan Pendidikan Indonesia, (Jakarta: Bumi Aksara, 2008).

Aswandi, Proses sebuah kebijakan, http://www.facebook.com/topic.php, Senin, 20 Juli 2009 , download tanggal 8 Januari 2011

Cecep Darmawan. Politik Pendidikan Indonesia. Harian Pikiran Rakyat, Senin 4 Mei 2009.

http://hidupuntukberfikir.blogspot.com/2010/12/politik-pendidikan-institusikekuasaan.html

http://Faihansyaddad.wordpress.com/2010/14/analisis-kebijakan-pendidikanislam-bidang-kurikulum

M. Sirozi, Politik pendidikan. (Jakarta : PT Raja Grafindo, 2005)

Syafaruddin, Evektivitas Kebijakan Pendidikan: konsep, strategi, dan aplikasi kebijakan menuju organisasi sekolah efektif, (Jakarta: Rineka Cipta, 2008)

Subandijah, Pengembangan dan Inovasi Kurikulum, (Jakarta :Raja Gravindo Persada, 1993

Tabrani \& Samsul Arifin, Islam Pluralitas Budaya dan Politik, (Yogyakarta: SI Press, 1994), 